\title{
Radioimmunoassay of Human Plasma
}

\section{Lecithin-Cholesterol Acyltransferase}

\author{
John J. Albers, Janet L. Adolphson, and Ching-Hong Chen, Department of \\ Medicine and Northwest Lipid Research Clinic, Harborview Medical Center, \\ University of Washington School of Medicine, Seattle, Washington 98104
}

A B S TRACT A sensitive and precise competitivedisplacement double-antibody radioimmunoassay was developed for the human plasma enzyme lecithincholesterol acyltransferase (LCAT; EC 2.3 1.43). The ability of plasma from various animal species to displace labeled human LCAT from goat anti-human LCAT could be ranked in the following order: man and sheep $>$ nonhuman primates $>$ cat or $\operatorname{dog}>$ pig $>$ rabbit or guinea pig $>$ mouse $>$ rat. Normolipidemic subjects had levels of LCAT of $6.14 \pm 0.98 \mu \mathrm{g} / \mathrm{ml}$ (mean $\pm \mathrm{SD}, n=66)$. Subjects with dysbeta-lipoproteinemia had the highest plasma LCAT levels $(7.88 \pm 0.39 \mu \mathrm{g} / \mathrm{ml}, n=7, P<0.05)$, followed by hypercholesterolemic subjects $(7.00 \pm 1.30, n=41)$ and hypertriglyceridemic subjects $(6.96 \pm 1.3, n=10)$. LCATdeficient subjects had the lowest enzyme levels $(0.89,0.83$, and $0.05 \mu \mathrm{g} / \mathrm{ml}$, respectively, and two subjects with no detectable enzyme). Males had lower LCAT levels $(6.42 \pm 1.05 \mu \mathrm{g} / \mathrm{ml}, n=90$, for all subjects; $5.99 \pm 1.03, n=44$, for normolipidemics) than females $(7.01 \pm 1.14, n=34$, for all subjects $P<0.01 ; 6.44 \pm 0.79$, $n=22$, for normolipidemics, $P<0.01)$. LCAT levels correlated significantly with total cholesterol (males, $r=0.384, P<0.001$; females, $r=0.519, P<0.002)$; and total triglyceride (only in females, $r=0.512$, $P<0.002)$. LCAT levels in females correlated inversely with HDL cholesterol $(r=-0.341, P<0.05)$ and apoprotein $\mathrm{D}(r=-0.443, P<0.02)$, but no such relationship existed in males.

\section{INTRODUCTION}

Plasma from many mammalian species contains an enzyme, lecithin-cholesterol acyltransferase (LCAT) ${ }^{1}$

Dr. Albers is an Established Investigator of the American Heart Association.

Received for publication 22 May 1980 and in revised form 25 July 1980.

${ }^{1}$ Abbreviations used in this paper: DTNB, 5,5'-dithiobis (2-nitrobenzoic acid); HDL, high density lipoproteins; LCAT, lecithin-cholesterol acyltransferase; LDL, low density lipoproteins; RIA, radioimmunoassay; VLDL, very low density lipoproteins.
(EC 2.3 1.43), which catalyzes the esterification of cholesterol by transferring a fatty acyl residue primarily from the carbon-2 position of phosphatidyl choline to the 3-hydroxyl group of unesterified cholesterol $(1,2)$. LCAT reacts preferentially with plasma high density lipoproteins (HDL) and is responsible for the formation of most of the cholesteryl esters found in human plasma $(1,2)$. Although this enzyme has been postulated to play a role in the removal of cholesterol from peripheral tissues, the physiological role of the enzyme is not yet fully established.

Cholesterol esterification in plasma is measured by a variety of chemical and radiochemical techniques. Although these assays may reflect the physiological esterification rate, they do not readily distinguish the influences of enzyme from those of the substrate, cofactors, and products. Subjects with derangements of lipoprotein metabolism may have lipoproteins with altered reactivity with LCAT, altered concentrations of the enzyme, or both. A direct measurement of the mass of the enzyme, coupled with a measurement of esterification rate, may permit differentiation of abnormalities of the enzyme from qualitative or quantitative substrate or cofactor abnormalities.

This study describes the development of a specific and sensitive radioimmunoassay for the human plasma LCAT enzyme and its first application to the measurement of LCAT in normolipidemic and hyperlipidemic subjects, and in five subjects with familial LCAT deficiency. The relationship of LCAT levels to lipid, lipoprotein, and apoprotein levels is described. In addition, the ability of LCAT from numerous animal species to displace human LCAT from its homologous antibody is examined.

\section{METHODS}

Preparation of antigen and antibody. LCAT was isolated from $1,500 \mathrm{ml}$ of fresh human plasma by a combination of ultracentrifugation and, affinity, anion, and absorption chromatography as described (3-5). To isolate LCAT used to immunize the goat, the $d=1.21-1.25$ fraction was isolated by sequential ultracentrifugation, dialyzed, and applied to a 
HDL-Sepharose affinity column (5). A protein peak containing enzyme activity was eluted with $0.5 \mathrm{mM}$ sodium taurocholate. This fraction was then separated on a DEAE-Sepharose CL-6B (Pharmacia Fine Chemicals, Inc., Piscataway, N.J.) column and eluted with a linear gradient of $\mathrm{NaCl}$. Protein containing LCAT activity was eluted at a $\mathrm{NaCl}$ concentration of $\sim 90-164 \mathrm{mM}$, pooled, dialyzed, and passed through a hydroxylapatite column. The enzyme was eluted with a linear phosphate gradient. A single protein peak containing enzyme activity was eluted at a phosphate concentration of 28-36 $\mathrm{mM}$ (5).

Recently, phenyl-Sepharose CL-4B affinity chromatography (Pharmacia Fine Chemicals) has been substituted for the HDL affinity chromatographic step for the preparation of LCAT used in the radioimmunoassay. The $d=1.21-1.25$ plasma fraction can be applied directly to the column without dialysis. Furthermore, the phenyl-Sepharose has greater binding capacity per milliliter bed volume than does the HDL affinity column. Specifically, $\sim 350 \mathrm{ml}$ of the $d=1.21-$ 1.25 plasma fraction containing $6-7 \mathrm{mg} / \mathrm{ml}$ of protein and 2.9 $\mathrm{M} \mathrm{KBr}$ was added to a $2.5 \times 26-\mathrm{cm}$ column containing 140 $\mathrm{ml}$ phenyl-Sepharose CL- $4 \mathrm{~B}$ equilibrated with radioimmunoassay (RIA) buffer (see below) at $4^{\circ} \mathrm{C}$. After binding the LCAT fraction, the column was washed with $900 \mathrm{ml}$ of RIA buffer at a flow rate of $60 \mathrm{ml} / \mathrm{h}$, and the enzyme was then eluted with $300 \mathrm{ml}$ of distilled water into $20-\mathrm{ml}$ fractions. A single protein peak containing LCAT activity was eluted in fractions 5 through 7 .

The purified LCAT preparation was homogenous by sodium dodecyl sulfate gel electrophoresis with an apparent molecular weight of $66,000 \pm 2,000(n=6)$. The amino acid analysis of the LCAT preparation was essentially as described $(4,5)$. Protein was determined by the method of Lowry et al. (6). Electrophoresis by the method of Davis (7), using an acrylamide monomer concentration of $7.5 \%$, separated out $\sim 50 \mu \mathrm{g}$ of the purified LCAT on each analytical polyacrylamide gel column $(0.7 \times 70 \mathrm{~cm})$. The single LCAT band was made visible with $0.5 \mathrm{mg} / \mathrm{dl}$ anilinonaphthalene sulfonate containing $25 \% \mathrm{Na}_{2} \mathrm{SO}_{4}$ to prevent diffusion, and a 1-2-mm section cut from each gel. The gel pieces containing $\sim 500 \mu \mathrm{g}$ of LCAT were ground into fine pieces with a mortar and pestle, mixed with $0.3 \mathrm{ml}$ of distilled water and an equal volume of complete Freund's adjuvant (Difco Laboratories, Detroit, Mich.), and emulsified by forcing the mixture back and forth through a 25-gauge needle. The emulsified gels were injected subcutaneously into a goat in the upper back and intramuscularly in the thigh. The goat was given a booster injection 7 and $14 \mathrm{~d}$ after the initial injection with $\sim 500 \mu \mathrm{g}$ of LCAT emulsified with incomplete Freund's adjuvant (Difco Laboratories). After the third injection, the goat was bled from the jugular vein. The blood was stored at $4^{\circ} \mathrm{C}$ overnight. It was then centrifuged, and the serum was decanted. The antiserum formed a single precipitation line with purified LCAT in gel diffusion studies. Apoproteins A-I, A-II, and D, low density lipoproteins (LDL) of $d=1.019-1.063$, very low density lipoproteins (VLDL) of $d=1.006$, or delipidated VLDL over a range of concentrations $(0.1-1 \mathrm{mg} / \mathrm{ml})$ did not visibly react with the anti-LCAT sera in gel diffusion studies. Immunoglobulin (Ig)G was isolated from the anti-LCAT sera by $16 \%$ (wt/vol) $\mathrm{Na}_{2} \mathrm{SO}_{4}$ precipitation and DEAE-Sepharose CL-6B chromatography using a modification of a method previously described (8). The column was equilibrated with $0.02 \mathrm{M}$ sodium phosphate, $\mathrm{pH}$ 6.8. The IgG was eluted with the nonbinding fraction. Similar attempts to produce anti-LCAT sera from a sheep and five different rabbits were unsuccessful.

Preparation of labeled LCAT. Purified LCAT was labeled with ${ }^{125} \mathrm{I}$, using the lactoperoxidase reaction coupled with glucose oxidase, glucose, and atmospheric oxygen to generate $\mathrm{H}_{2} \mathrm{O}_{2}$ at a controlled rate $(9,10)$, and using the enzymobead lactoperoxidase glucose oxidase reagent ( $\mathrm{Bio}-$ Rad Laboratories, Richmond, Calif.). The enzymobead reagent $(50 \mu \mathrm{l})$ was added to $20 \mu \mathrm{g}$ of LCAT in $50-100 \mu \mathrm{l}$ of $0.2 \mathrm{M}$ potassium phosphate buffer, $\mathrm{pH} 7.2$. Next, $0.5 \mathrm{mCi}$ of carrier-free $\mathrm{Na}^{125} \mathrm{I}$ (New England Nuclear, Boston, Mass.) $25 \mathrm{mCi} / \mathrm{ml}$ sp act, and $50 \mu \mathrm{l}$ of $0.1 \% \alpha-\mathrm{D}$ glucose were added, mixed, and then incubated for $30 \mathrm{~min}$ at room temperature. To remove the enzymobeads containing lactoperoxidase, the reaction mixture was centrifuged at $2,000 \mathrm{rpm}$ for $20 \mathrm{~min}$ $\left(11,000 \mathrm{~g}\right.$-min) at $4^{\circ} \mathrm{C}$; the supernate was applied at room temperature to a Sephacryl S-200 column $(0.9 \times 40 \mathrm{~cm})$ equilibrated with $10 \mathrm{mM}$ Tris, $150 \mathrm{mM} \mathrm{NaCl}, 1 \mathrm{mM}$ EDTA, pH 7.4 (designated as RIA buffer), and $1 \%$ bovine serum albumin (fraction V, Sigma Chemical Co., St. Louis, Mo.), and eluted with a flow rate of $10 \mathrm{ml} / \mathrm{h}$. Fractions $(0.3 \mathrm{ml})$ were collected and monitored with an autogamma counter (Nuclear-Chicago Corp., Des Plaines, Ill.). At an elution volume of $60 \mathrm{ml}$ or greater, the tubes contained chiefly free ${ }^{125} \mathrm{I}$. The major protein fraction with an elution volume of 31-39 ml was dialyzed exhaustively against RIA buffer plus $20 \mathrm{mM} \mathrm{KI}$. This dialyzed fraction with a specific activity of $3 \times 10^{6} \mathrm{cpm} / \mu \mathrm{g}$ of protein was used in the LCAT radioimmunoassay.

Plasma samples. Plasma samples were obtained from subjects after an overnight fast. Blood was obtained from healthy adult volunteers and from subjects with hyperlipidemia referred to the Northwest Lipid Research Clinic. Serum obtained from subjects with familial LCAT deficiency was kindly provided by Dr. John Glomset of the Department of Medicine, University of Washington, Seattle, Wash., Dr. Kaare Norum, University of Oslo, Oslo, Norway, (patients M.R., M.L., and A.A.), and Dr. J. Frohlich of Vancouver General Hospital, Vancouver, British Columbia, Canada (patients D.H. and S.F.). Documentation of the LCAT deficiency of these patients has been previously reported $(11,12)$.

Analytical methods. Plasma cholesterol and triglyceride, and lipoprotein-cholesterol assays were performed by standardized methods of the Lipid Research Clinic Program (13). For preparation of the $d<1.063$ and the $d=1.063-$ 1.21 plasma fractions, fresh plasma was brought to a density of 1.063 with solid $\mathrm{KBr}$ and centrifuged at 40,000 rpm for $24 \mathrm{~h}$ at $4^{\circ} \mathrm{C}$ in a 40.3 rotor (Beckman Instruments, Spinco Div., Palo Alto, Calif.). The top one-third of the tube was sliced, and the $d<1.063$ fraction was removed. The bottom fraction was brought to $d=1.21$ with $\mathrm{KBr}$ and centrifuged at $39,000 \mathrm{rpm}$ for $26 \mathrm{~h}$ at $4^{\circ} \mathrm{C}$. The top one-third of the tube was sliced, and the top $d=1.063-1.21$ fraction was removed. All fractions were dialyzed against RIA buffer. Some plasma samples were delipidated with ethanol-diethyl ether $3: 1$ (vol/ vol) (14), methanol-diethyl ether $3: 1$ (15), or heptane after lyophilization in the presence of starch (16), and then redissolved in RIA buffer before radioimmunoassay.

Apoprotein A-I and A-II quantification was performed by radial immunodiffusion $(17,18)$. Apoproteins A-I and A-II were prepared as described (18). Similarly, apoprotein D was measured by radial immunodiffusion, but instead of treating plasma with dissociating agents, whole plasma was added directly to the gel plate. Apoprotein D was prepared by hydroxylapatite chromatography of delipidated HDL (19). Delipidation of plasma with combinations of organic solvents $(14,15)$ did not alter the apoprotein D immunoreactivity. ${ }^{2}$

${ }^{2}$ Albers, J. J., M. C. Cheung, and S. Ewens, unpublished observations. 
To measure the plasma esterification rate, $0.2 \mathrm{ml}$ of fresh plasma containing $1.5 \mathrm{mg} / \mathrm{ml}$ of disodium EDTA was incubated in quadruplicate on ice or at $37^{\circ} \mathrm{C}$ in a shaking water bath for $40 \mathrm{~min}$. The LCAT reaction was stopped by the addition of $2 \mathrm{ml}$ of ethanol, and the sample extracted with hexane (20). The hexane extract was then evaporated dry, and the unesterified cholesterol determined by the Merck enzymatic method (E. Merck, Darmstadt, Federal Republic of Germany) as described by Dieplinger and Kostner (21). LCAT activity of the purified enzyme was determined from the conversion of $\left[4-{ }^{14} \mathrm{C}\right]$ cholesterol to labeled cholesteryl ester in the presence of egg lecithin, apoprotein A-I, human serum albumin, and mercaptaethanol as described by Albers et al. (5). Esterification was tested after preincubating substrate with apoprotein for $30 \mathrm{~min}$ before adding enzyme.

RIA conditions. Assay conditions were designed for optimal measurement of LCAT at a 1:50 dilution of plasma. The dilution of antibody was chosen to precipitate $\sim 50 \%$ of the radioactivity precipitated with a 1:20 dilution of anti-LCAT sera. To each $10 \times 75-\mathrm{mm}$ glass tube precoated with Column Coat (Miles Laboratories, Inc., Ames Div., Elkhart, Ind.) was added $100 \mu$ l of sample or standard, followed by $100 \mu \mathrm{l}$ of ${ }^{125}$ I-LCAT $(0.03 \mu \mathrm{g} / \mathrm{ml})$, and then $100 \mu \mathrm{l}$ of goat anti-human LCAT sera (diluted 1:450). The standard ranged from 0.04 to $0.2 \mu \mathrm{g} / \mathrm{ml}$. Samples and standards were diluted with RIA buffer containing $1 \%(\mathrm{vol} / \mathrm{vol})$ albumin and $0.1 \%$ (vol/vol) Tween 20 (Sigma Chemical Co.). Plasma samples were diluted 1:50. After incubation at $4^{\circ} \mathrm{C}$ for $48 \mathrm{~h}, 100 \mu \mathrm{l}$ of normal goat serum diluted 1:100 and $300 \mu \mathrm{l}$ of rabbit anti-goat IgG were added sequentially to each tube. The radioactivity was measured, and the tubes were incubated overnight $(15-18 \mathrm{~h})$ at $4^{\circ} \mathrm{C}$. The tubes were centrifuged at $3,000 \mathrm{rpm}$ for $30 \mathrm{~min}$ $\left(60,000 \mathrm{~g}\right.$-min) at $4^{\circ} \mathrm{C}$ in the Sorvall RC3 centrifuge (DuPont Instruments, Sorvall Biomedical Div., Newtown, Conn.). The precipitates were washed three times with RIA buffer containing $1 \%$ albumin and then measured for radioactivity. Each assay contained control tubes in which (a) RIA buffer was substituted for anti-LCAT sera to measure nonspecific precipitation, and $(b)$ instead of the normal dilution of antiLCAT sera, conditions were used to give maximal immunoprecipitation, e.g., a 1:20 dilution of anti-LCAT sera. Occasionally, a large excess $(50 \mu \mathrm{g})$ of unlabeled LCAT was added to the usual assay mixture. All samples were assayed in triplicate. An aliquot from two plasma pools was measured in each assay. The plasma pools were stored at $4^{\circ} \mathrm{C}$ in sealed 5 -ml vials (Wheaton Scientific, Millville, N.J.). They contained $0.5 \mathrm{~g} /$ liter sodium azide, $0.01 \mathrm{~g} /$ liter chloramphenicol, and $0.005 \mathrm{~g} /$ liter gentamycin.

Calculations and statistics. Assay data were calculated with a Tektronix programmable desk calculator (Tektronix, Inc., Beaverton, Oreg.), using a program provided by the vendor that linearizes the relationship between percent antigen bound $\left(\mathrm{B} / \mathrm{B}_{\mathrm{o}}\right)$ and $\log$ dose (unlabeled LCAT) by the logit transformation. In plots of the standard curve, $y=\operatorname{logit} B / B_{0}$ and $x=\log$ dose of antigen, where logit $B / B_{0}=\ln \left(B / B_{0} \div\left[1-B / B_{0}\right]\right), B_{0}=$ net counts in the absence of test sample or LCAT standard (radioactivity precipitated when no unlabeled LCAT is added to the assay mixture minus radioactivity in nonspecific precipitate), $B=$ net counts in the presence of test sample or LCAT standard (radioactivity precipitated minus radioactivity in nonspecific precipitate).

Mean differences between groups were tested using the two-sample $t$ test. Test for equality of slopes was also determined by $t$ test. Pearson's correlation coefficient $(r)$ was used to show the degree of linear association betweeen the

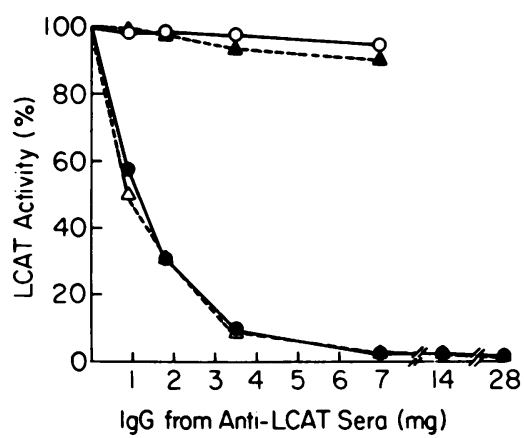

FIGURE 1 Inhibition of LCAT activity with IgG from antiLCAT sera. Fresh plasma or purified LCAT $(0.3 \mathrm{ml})$ was incubated with an equal volume of nonimmune IgG $(O$, plasma; $\Delta$, purified LCAT) or IgG from anti-LCAT sera (, , plasma; $\triangle$, purified LCAT) at the indicated concentrations for $1 \mathrm{~h}$ at $37^{\circ} \mathrm{C}$ and then for $12 \mathrm{~h}$ at $4^{\circ} \mathrm{C}$. After the mixture was centrifuged at $4^{\circ} \mathrm{C}$ at $11,000 \mathrm{~g}$-min, the supernatant solution was analysed for LCAT activity. Plasma in the absence of IgG converted $71 \mathrm{nmol}$ cholesterol $\cdot \mathrm{h}^{-1} \cdot \mathrm{ml}^{-1}$. Purified LCAT ( $1 \mu \mathrm{g}$ ) converted $9 \mathrm{nmol}$ cholesterol $\cdot \mathrm{h}^{-1} \cdot \mathrm{ml}^{-1}$ using cholesterol-lecithin vesicles as substrate.

different variables. The significance of $r$ was found from the $t$ distribution using the formula $t_{n-2}=\sqrt{(n-2)\left(1-r^{2}\right)}$. Alternatively, Spearman's rank correlation coefficient was used to determine the association between the variables (22).

\section{RESULTS}

LCAT inhibition with antibody. Preincubation of plasma with immunoglobulin isolated from the specific anti-LCAT sera (see Methods) completely inhibited the plasma LCAT activity (Fig. 1). Preincubation of plasma with immunoglobulin from nonimmune sera, however, had little effect on plasma LCAT activity. Similarly, preincubation of purified enzyme with immunoglobulin from anti-LCAT sera completely inhibited all enzyme activity (Fig. 1).

Validation of the assay. According to conditions described for maximum precipitation (1:20 dilution of antisera), $86.4 \pm 2.6 \%$ (mean $\pm \mathrm{SD})(n=8)$ of the radioactivity was precipitable with anti-LCAT sera. Only $0.7 \pm 0.3 \%$ of the radioactivity was precipitated with nonimmune goat serum (nonspecific control). Under normal assay conditions (1:450 dilution of antisera), $50 \mu \mathrm{g}$ of unlabeled LCAT displaced $92 \%$ of the radioactivity. Furthermore, there was very little displacement of radioactivity $(<2 \%)$ by the addition of physiological concentrations of LDL, VLDL, delipidated VLDL, and apolipoproteins A-I, A-II, and D. Antisera diluted 1:450 precipitated $58.1 \pm 6.0 \%$ (six assays) of the radioactivity that was precipitable with a 1:20 dilution of the antisera.

The relationship between the percent antigen bound $\left(B / B_{0}\right)$ and $\log$ of the unlabeled antigen dose was linearized by applying the logit transformation to 




FIgURE 2 The LCAT RIA standard curve (O). Competitive displacement of human ${ }^{125}$ I-labeled LCAT from goat antihuman LCAT by purified unlabeled LCAT. Competitive displacement of labeled LCAT from anti-LCAT by purified LCAT (๑), normal plasma $(\nabla)$, HDL fraction of $d=1.063$ $1.21(\triangle)$, and LCAT-deficient plasma from M.R. (O), A.A. ( $\square$ ),

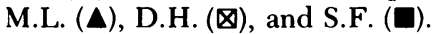

$\mathrm{B} / \mathrm{B}_{\mathrm{o}}$ (see Methods). The correlation coefficient $(r)$ of the logit of $B / B_{0}$ vs. $\log$ antigen dose averaged $-0.998 \pm 0.001$ and the slope $-2.08 \pm 0.11($ mean \pm SD) $(n=6)$. The concentration of unlabeled LCAT required to obtain a $B / B_{0}$ of 0.5 was $146 \pm 17 \mathrm{ng} / \mathrm{ml}$ $(n=8)$. The lower limit of sensitivity of the assay, that is, the dose of antigen needed to produce a response 2 SD from the zero dose response, was $\sim 21 \mathrm{ng} / \mathrm{ml}$. As little as $50 \mathrm{ng} / \mathrm{ml}$ of LCAT could be reliably detected with a coefficient variation of $\sim 14 \%$. All six plasma samples examined, including two hypertriglyceridemic samples, displayed parallelism with the LCAT standard. For example, the displacement curve obtained with standard had a slope of -2.10 and that with normal plasma a slope of -2.05 (Fig. 2). To test recovery of purified LCAT, $20 \mathrm{ng}$ of LCAT standard was added to each of three plasma samples. The mean recovery of the purified LCAT was $101 \%$.

To assess between-assay reproducibility, two plasma samples stored at $4^{\circ} \mathrm{C}$ in sealed 5 -ml vials were analyzed each assay day. Their means and standard deviations were as follows: $7.34 \pm 0.44 \mathrm{ng} / \mathrm{ml}, n=7$, coefficient of variation $=6.0 ; 5.25 \pm 0.47 \mathrm{ng} / \mathrm{ml}, n=7$, coefficient of variation $=8.9 \%$. Thus, the between-assay variation ranged from 6 to $9 \%$ for most plasma samples.

To test whether lipids mask the antigenic determinants of LCAT or in some way decrease the reactivity of LCAT for the LCAT antibody, the plasma lipids were extracted with methanol-diethyl ether or with ethanol-diethyl ether (see Methods). To each plasma sample was added $1 \mu \mathrm{g}$ of labeled LCAT to estimate protein recovery of the delipidation steps. The LCAT concentration of six plasma samples was $6.21 \pm 0.36 \mu \mathrm{g} / \mathrm{ml}$, but only $1.59 \pm 0.37 \mu \mathrm{g} / \mathrm{ml}$ after extraction with methanol-ether and only $2.0 \pm 0.7 \mu \mathrm{g} / \mathrm{ml}$ after extraction with ethanol-ether. An average of $87 \%$ of the labeled LCAT was recovered after methanolether extraction and $75 \%$ was recovered after ethanolether extraction. Thus, after correction for losses due to delipidation, we find that methanol-ether extraction reduced the apparent concentration of plasma LCAT $\sim 71 \%$ and ethanol-ether treatment reduced the concentration $\sim 57 \%$.

Because nearly complete extraction of lipids may alter the conformation of the LCAT protein such that its reactivity with antibody is decreased, additional plasma samples were extracted by a milder procedure involving only partial extraction of the lipids with heptane (see Methods). Plasma samples that underwent partial lipid extraction by this method had LCAT values only slightly lower $(8 \%$ on the average) than untreated plasma $(6.70 \pm 0.60$ compared with $7.27 \pm 0.73 \mathrm{ng} / \mathrm{ml}, n=6)$. $96 \%$ of the labeled LCAT was recovered after the heptane treatment. Thus, the immunoreactivity of plasma samples after partial delipidation was nearly identical to those before delipidation. Also, preincubation of plasma with $0.1 \%$ Tween 20 (final concentration) had no effect on the LCAT immunoreactivity.

Effect of freezing on the measurement of LCAT in plasma. Aliquots of 27 fresh plasma samples were quick-frozen in acetone with dry ice and placed in a $-20^{\circ} \mathrm{C}$ freezer. Separate aliquots were placed directly in a $-60^{\circ} \mathrm{C}$ freezer. The next day all samples were analyzed for LCAT by radioimmunoassay. The LCAT values of the fresh samples $(5.42 \pm 1.11 \mu \mathrm{g} / \mathrm{ml}, n=27)$ were not significantly different, as determined by paired $t$ test, from aliquots of the quick-frozen samples $(5.70 \pm 1.07 \mu \mathrm{g} / \mathrm{ml})$ or from those placed in a $-60^{\circ} \mathrm{C}$ freezer $(5.84 \pm 1.13 \mu \mathrm{g} / \mathrm{ml})$. Furthermore, the values on fresh plasma were highly correlated with both sets of frozen samples $(r=0.90$ and 0.91 , respectively). Furthermore, storage of plasma samples for 2 mo at $4^{\circ} \mathrm{C}$ did not alter the immunoreactivity of LCAT.

LCAT in plasma fractions. LCAT in the $d=1.063-$ 1.21 HDL fraction produced a displacement curve parallel to that obtained with whole plasma or purified enzyme (Fig. 2), indicating the immunological similarity of the LCAT-lipid complex in the HDL fraction and that of the purified enzyme. Approximately half of the total enzyme in plasma was recovered in the HDL fraction, and $31 \pm 7 \%$ was recovered in the $d>1.21$ fraction (Table I). Negligible amounts of enzyme were obtained in the $d<1.063$ fraction $(0.6 \pm 0.3 \%)$. Approximately $19 \%$ of the total LCAT was lost by the fractionation and subsequent dialysis procedures. Addition of the LCAT inhibitor 5,5'-dithiobis (2nitrobenzoic acid) (DTNB) to the plasma before fractionation did not significantly affect the distribution of LCAT in the plasma fractions (Table I). 
TABLE I

Distribution of LCAT in Plasma Density Fractions

\begin{tabular}{lrrrrr}
\hline \multirow{2}{*}{$\begin{array}{l}\text { Plasma or density } \\
\text { fraction }\end{array}$} & \multicolumn{2}{c}{ LCAT } & & \multicolumn{2}{c}{ Percentage of total LCAT } \\
\cline { 2 - 3 } \cline { 5 - 6 } & \multicolumn{1}{c}{ +DTNB } & -DTNB & & +DTNB & -DTNB \\
\hline Plasma & \multicolumn{3}{c}{$\mu g / m l$} & & $\%$ \\
$d<1.063$ & & $6.12 \pm 0.27$ & & & \\
$d=1.063-1.21$ & $0.04 \pm 0.02$ & $0.03 \pm 0.01$ & & $0.6 \pm 0.4$ & $0.5 \pm 0.2$ \\
$d>1.21$ & $2.94 \pm 0.30$ & $3.13 \pm 0.28$ & & $48.3 \pm 6.6$ & $51.3 \pm 6.1$ \\
& $1.72 \pm 0.48$ & $2.10 \pm 0.51$ & & $28.2 \pm 7.8$ & $34.3 \pm 7.9$ \\
\hline
\end{tabular}

Fresh plasma from four normolipidemic healthy adults was fractionated by sequential ultracentrifugation in the absence or presence of $1.6 \mathrm{mM}$ DTNB, an LCAT inhibitor. Results expressed as mean $\pm \mathrm{SD}$.

LCAT concentration in LCAT deficiency. The displacement curves obtained with LCAT-deficient plasma from two subjects, M.R. with a slope of -2.04 and A.A. with a slope of -2.04 , were parallel to that obtained with the LCAT standard with a slope of -2.10 (Fig. 2). However, the concentration of LCAT in these two LCAT-deficient plasma samples was $\sim 10-15 \%$ of that found in normal plasma. M.R. had an LCAT concentration of $0.89 \mu \mathrm{g} / \mathrm{ml}$, and A.A., $0.83 \mu \mathrm{g} / \mathrm{ml}$. Normal plasma contains $\sim 5-8 \mu \mathrm{g}$ LCAT $/ \mathrm{ml}$. Another LCAT-deficient patient, M.L., had an apparent concentration of $0.05 \mu \mathrm{g} / \mathrm{ml}$, whereas plasma from two other LCAT-deficient patients, S.F. and D.H., gave negligible displacement of labeled LCAT and therefore appeared to contain $<0.02 \mu \mathrm{g} / \mathrm{ml}$ of LCAT (below the sensitivity of the assay).

Plasma LCAT concentration in normolipidemic and hyperlipidemic subjects. Plasma LCAT levels in normolipidemic and hyperlipidemic subjects are shown in Table II. Hypercholesterolemic subjects and hypertriglyceridemic females tended to have higher plasma levels of LCAT than did normolipidemic subjects
$(P<0.01)$. Subjects with dysbeta-lipoproteinemia had significantly higher levels of LCAT than did normolipidemic subjects or hypertriglyceridemic males $(P<0.01)$ and somewhat higher levels than hypercholesterolemic subjects $(P<0.05)$. Males had slightly lower plasma LCAT levels $(6.42 \pm 1.25 \mu \mathrm{g} / \mathrm{ml}, n=90)$ than did the females $(7.01 \pm 1.14 \mu \mathrm{g} / \mathrm{ml}, n=34, P<0.01)$. Examination of the normolipidemic, hypercholes: terolemic, and hypertriglyceridemic groups also indicated that males generally had lower levels than did females (Table II).

LCAT concentration: relationship to lipid, lipoprotein, and apoprotein levels. Plasma cholesterol in males and females, plasma triglyceride and VLDL cholesterol in females, and LDL cholesterol in males were all significantly correlated with plasma LCAT concentrations (Table III). HDL cholesterol (Table III) and apoprotein D (not shown) were inversely correlated with LCAT mass in females $(r=-0.443, n=29$, $P<0.02$ ), but had no relationship with LCAT mass in males. The HDL apoproteins A-I or A-II did not correlate significantly with plasma LCAT concentra-

TABLE II

LCAT Concentration in Plasma

\begin{tabular}{|c|c|c|c|c|c|c|c|c|c|c|c|}
\hline \multirow[b]{2}{*}{ Subject group } & \multirow[b]{2}{*}{$n$} & \multicolumn{2}{|c|}{ Sex } & \multicolumn{2}{|c|}{ Plasma LCAT } & \multicolumn{2}{|c|}{ Cholesterol } & \multicolumn{2}{|c|}{ Triglyceride } & \multicolumn{2}{|c|}{ HDL cholesterol } \\
\hline & & $\mathbf{M}$ & $\mathbf{F}$ & $\mathbf{M}$ & $\mathbf{F}$ & $\mathbf{M}$ & $\mathbf{F}$ & $\mathbf{M}$ & $\mathbf{F}$ & $\mathbf{M}$ & $\mathbf{F}$ \\
\hline & & & & \multicolumn{2}{|c|}{$\mu g / m l$} & \multicolumn{2}{|c|}{$m g / d l$} & \multicolumn{2}{|c|}{$m g / d l$} & \multicolumn{2}{|c|}{$m g / d l$} \\
\hline $\begin{array}{l}\text { Normo- } \\
\text { lipidemic }\end{array}$ & 66 & 44 & 22 & $5.98 \pm 1.04$ & $6.44 \pm 0.81$ & $213 \pm 36$ & $188 \pm 25$ & $125 \pm 56$ & $97 \pm 46$ & $50.5 \pm 15.0$ & $57.4 \pm 14.8$ \\
\hline $\begin{array}{l}\text { Hypercholes- } \\
\text { terolemic* }\end{array}$ & 41 & 39 & 2 & $6.98 \pm 1.32$ & 7.35 & $288 \pm 32$ & 276 & $144 \pm 48$ & 113 & $42.9 \pm 8.8$ & 59.0 \\
\hline $\begin{array}{l}\text { Hypertriglycer- } \\
\text { idemic* }\end{array}$ & 10 & 6 & 4 & $5.81 \pm 0.70$ & $8.68 \pm 1.15$ & $209 \pm 38$ & $363 \pm 112$ & $254 \pm 59$ & $996 \pm 757$ & $33.7 \pm 5.7$ & $32.8 \pm 9.1$ \\
\hline proteinemict & 7 & 1 & 6 & 7.98 & $7.86 \pm 0.46$ & 888 & $489 \pm 286$ & 3420 & $1419 \pm 78$ & 16.0 & $52.5 \pm 23.1$ \\
\hline
\end{tabular}

Results expressed as mean $\pm S D$.

* Lipid level $>95$ th percentile for subject's age and sex.

† Subjects had cholesterol-rich $(d<1.006)$ lipoproteins and $\mathbf{E}_{3}$ deficiency characteristic of type III hyperlipoproteinemia (23). 
TABLE III

Correlation of Plasma LCAT Levels with Lipids and Lipoproteins

\begin{tabular}{lccrrc}
\hline \multirow{2}{*}{\multicolumn{1}{c}{ Variable }} & \multicolumn{2}{c}{ Male } & & \multicolumn{2}{c}{ Female } \\
\cline { 2 - 3 } \cline { 5 - 6 } & $r$ & $P$ & & $r$ & $P$ \\
\hline Plasma cholesterol & 0.384 & $<0.001$ & & 0.519 & $<0.002$ \\
Plasma triglyceride & 0.131 & NS & & 0.512 & $<0.002$ \\
VLDL cholesterol & 0.137 & NS & & 0.490 & $<0.005$ \\
LDL cholesterol & 0.331 & $<0.002$ & & 0.123 & NS \\
HDL cholesterol & 0.041 & NS & -0.341 & $<0.05$ \\
\hline
\end{tabular}

Study population includes 90 males and 34 females with the distribution of lipid profiles as shown in Table II.

tions (not shown). Analysis of the data using Spearman's nonparametric correlation corroborated these conclusions.

The smaller variance in triglyceride (Table II) or VLDL cholesterol in the males may in part explain the lack of correlation between LCAT and triglycerides or VLDL cholesterol in males. Furthermore, the smaller variance in LDL cholesterol in the females may explain the lack of correlation between LCAT and LDL cholesterol in females. The reason why HDL cholesterol and apoprotein D were not negatively correlated with LCAT in males is unclear, because the variance in these variables was similar in males and females.

LCAT in nonhuman species. Plasma samples from a variety of species were examined for their ability to displace ${ }^{125}$ I-labeled human LCAT from goat antihuman LCAT (Fig. 3). All five of the nonhuman primates examined produced displacement curves that were not parallel to that obtained with human plasma. Human plasma produced a displacement curve with a slope of -2.05 and plasma from the nonhuman primates produced shallower slopes of -1.49 (Japanese macaque, Macaca fuscata), - 1.47 (pigtail monkey, $M$. nemistrina), and -1.44 (rhesus monkey, $M$. mulatta) (Fig. 3); and -1.37 (baboon, Papio papio) and -1.28 (cynomolgus monkey, M. fasicularis) (not shown). Plasma from a sheep produced a slope of -2.09 , parallel to that formed with human plasma (Fig. 3). Plasma from three other sheep also produced slopes parallel to that found with human plasma. The apparent LCAT concentration of sheep plasma was $4.25 \pm 0.88 \mu \mathrm{g} / \mathrm{ml}(n=4)$, in a concentration range slightly lower than that found for human plasma. Plasma from other species was much less effective than was human plasma in displacing the labeled LCAT, yielding displacement curves with slopes of -1.02 (cat), -1.00 (dog), 0.74 (pig), -0.63 (guinea pig), and -0.61 (rabbit) (Fig. 3). Plasma from mice or rats produced little displacement (Fig. 3). Therefore, the ability of the plasma from various animal species to displace labeled human LCAT from goat antihuman LCAT could be ranked in the following order: man and sheep $>$ nonhuman primates (Japanese macaque, pigtail, cynomolgus, and rhesus monkeys, and baboon) $>$ cat or $\operatorname{dog}>$ pig, rabbit, or guinea pig $>$ mouse $>$ rat.

\section{DISCUSSION}

This report describes for the first time a specific, sensitive, and precise immunoassay for the human plasma enzyme LCAT. The assay appears to be a valid and specific measure of this enzyme by a number of criteria. First, preincubation of whole plasma or purified enzyme with anti-LCAT sera completely inhibited the LCAT reaction. Second, $<2 \%$ of the total radioactivity was displaced by VLDL, LDL, and a variety of apoproteins. Third, and most importantly, plasma from two LCAT-deficient patients failed to displace the labeled LCAT from its homologous antibody. Fourth, lipoprotein-bound and purified enzyme produced parallel displacement curves. Fifth, partial or complete dissociation of lipid from the enzyme failed to enhance the enzyme's immunoreactivity.

Surprisingly, LCAT from sheep appeared to be immunologically identical to human LCAT, because the displacement curve produced by the sheep sera was parallel to that formed by human sera. Although this finding suggests that sheep LCAT is quite similar structurally to that of human LCAT, it is possible that significant immunological differences could be observed between the LCAT of the two species if the immunological conditions were altered or if different antisera were used, particularly if the antisera were derived from species other than the goat. As expected, with the exception of the sheep, plasma from the

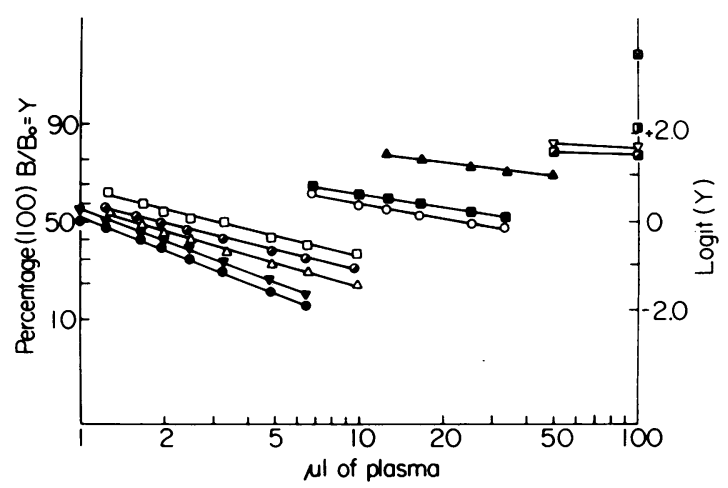

FIGURE 3 Competitive displacement of human ${ }^{125}$ I-labeled LCAT from goat anti-human LCAT by plasma from a human $(\odot)$, sheep $(\nabla)$, Japanese macaque (M. fuscata) $(\Delta)$, pigtail monkey (M. nemistrina) (O), rhesus monkey (M. mulatta) $(\square)$, cat $(O)$, dog $(\square)$, pig $(\boldsymbol{\Delta})$, rabbit $(\square)$, guinea pig $(\nabla)$,

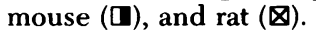


nonhuman primates appeared immunologically most similar to that of human plasma.

The finding that most of the LCAT mass was recovered in the $d=1.063-1.21$ fraction suggests that the enzyme has a high affinity for lipoprotein particles in the HDL range. It is likely that ultracentrifugation alters the lipoprotein distribution of LCAT. Because the amounts of enzyme found in the HDL fraction were approximately the same whether or not the plasma fractionation was performed in the presence of DTNB, it appears that enzyme activity is not required for the enzyme to bind to the HDL fraction. The availability of specific anti-LCAT sera should now allow the isolation and characterization of these LCAT-HDL complexes through application of specific antibody-affinity chromatography.

Understanding of the role of LCAT in normal lipoprotein metabolism has been enhanced considerably through studies of patients with familial LCAT deficiency $(11,24)$. It is believed that the lack of enzyme activity in the plasma of these subjects is due to the complete absence of the enzyme (11). Two subjects with familial LCAT deficiency from different families from the same region of Norway (M.R. and A.A.), have low but significant levels ( $>10 \%$ of normal) of the enzyme in their plasma. They appear to have a complete lack of LCAT activity (11), which suggests these subjects have low levels of a functionally defective enzyme in their plasma. It should be noted that the LCAT in these LCAT-deficient subjects appeared to be immunologically similar to LCAT in normal subjects. Plasma from a LCAT-deficient patient (M.L.) from a family in Sweden contained very low ( $<1 \%$ of normal) but detectable levels of enzyme mass. This Swedish patient differs from the Norwegian patients in that she has low ( $<10 \%$ of normal) but detectable levels of enzyme activity in her plasma $(11,25)$. Thus, her defect is consistent with very low levels of normal functional enzyme. In contrast to these three patients, the two Canadian LCAT-deficient subjects from the same family (D.H. and S.F.) contained essentially no detectable enzyme mass or activity. Thus, these preliminary studies suggest that different mutations may be involved in the production of familial LCAT deficiency.

Although a number of reports have suggested that males tend to have higher LCAT activity than do females (26-28), the males in this study tended to have lower LCAT mass than females. These observations suggest the possibility that the plasma of males and females differ significantly in substrate or cofactor properties. Plasma from hyperlipidemic subjects has been reported to have higher initial esterification rates than plasma from normolipidemic subjects $(28,29)$. It has been unclear whether hyperlipidemic subjects have increased concentrations of enzyme or have better or more available substrate. Findings in this study of higher LCAT levels in hyperlipidemic subjects and a significant positive correlation of LCAT with cholesterol and triglyceride levels suggest that hyperlipidemic subjects have higher esterification rates, in part because of increased enzyme concentration. It should be noted that the subjects with type III hyperlipoproteinemia, with the highest levels of both cholesterol and triglyceride, had the highest LCAT levels. Furthermore, these findings are consistent with the concept that increased triglyceride secretion is associated with increased LCAT secretion (30). It should be emphasized, however, that we cannot asume that the amount of immunoreactive enzyme correlates directly with the enzyme's catalytic activity. Verification of this assumption must await studies of LCAT mass coupled with the measurement of enzymatic activity of LCAT, using a common substrate method (31), and the assay of the initial esterification rate, using the subject's plasma as substrate. A failure to establish an association between immunoreactive LCAT levels and enzyme activity could suggest the presence of an inactive on nonfunctional enzyme, as appears to be the case with at least two of the LCAT-deficient subjects.

The RIA for human plasma LCAT represents a major advance in our technology, which can be applied to enhance our understanding of the role of LCAT in normal and abnormal lipoprotein metabolism.

\section{ACKNOWLEDGMENT}

This research was supported in part by grant HL-15263 and Contract NIHV 12157A from the Lipid Metabolism Branch, National Heart, Lung, and Blood Institute.

\section{REFERENCE}

1. Glomset, J. A. 1968. The plasma lecithin-cholesterol acyltransferase reaction. J. Lipid Res. 9: 155-167.

2. Glomset, J. A. 1972. Plasma lecithin: cholesterol acyltransferase. In Blood Lipids and Lipoproteins: Quantitation, Composition, and Metabolism. G. J. Nelson, editor. WileyInterscience, New York. 745-787.

3. Albers, J. J., V. G. Cabana, and Y. D. B. Stahl. 1976. Purification and characterization of human plasma lecithin-cholesterol acyltransferase. Biochemistry. 15: 1084- 1087.

4. Albers, J. J. 1978. Effect of human plasma apolipoproteins on the activity of purified lecithin-cholesterol acyltransferase. Scand. J. Clin. Lab. Invest. 38: 48-52.

5. Albers, J. J., J-T. Lin, and G. P. Roberts. 1979. Effect of human plasma apolipoproteins on the activity of purified lecithin-cholesterol acyltransferase. Artery. 5: 61-75.

6. Lowry, O. H., N. J. Rosebrough, A. L. Farr, and R. J. Randall. 1951. Protein measurement with the Folin phenol reagent. J. Biol. Chem. 193: 265-275.

7. Davis, B. J. 1974. Disc electrophoresis. II. Method and application to human serum proteins. Ann. N.Y. Acad. Sci. 121: 404-427.

8. Gilman, A. M., A. Nisonoff, and S. Dray. 1964. Symmetrical distribution of genetic markers in individual 
rabbit $\gamma$-globulin molecules. Immunochemistry. 1: 109120.

9. Schenkein, I., M. Levy, and J. W. Uhr. 1972. The use of glucose oxidase as a generator of $\mathrm{H}_{2} \mathrm{O}_{2}$ in the enzymatic radioiodination of components of cell surfaces. Cell. Immunology. 5: 490-493.

10. Hubbard, A. L., and Z. A. Cohn. 1972. The enzymatic iodination of the red cell membrane. J. Cell Biol. 55: 390-405.

11. Gjone, E., K. R. Norum, and J. A. Glomset. 1978. Familial lecithin: cholesterol acyltransferase deficiency. In. The Metabolic Basis of Inherited Disease. J. B. Stanbury, J. B. Wyngaarden, and D. S. Fredrickson, editors. McGraw-Hill Book Co., New York. 589-603.

12. Frohlich, J., W. J. Godolphin, C. E. Reeve, and K. A. Evelyn. 1978. Familial LCAT deficiency: report of two patients from a Canadian family of Italian and Swedish Descent. Clin. Lab. Invest. 38: 156-161.

13. Lipid Research Clinics Program Manual of Laboratory Operations, Vol. 1, Department of Health, Education and Welfare Publication No. (NIH) 75-628, 1974.

14. Albers, J. J., and A. M. Scanu. 1971. Isoelectric fractionation and characterization of polypeptides from human serum very low density lipoproteins. Biochim. Biophys. Acta. 236: 29-37.

15. Herbert, P. N., L. L. Bausserman, L. L. Henderson, R. J. Heinen, M. La Piana, E. C. Church, and R. S. Shulman. 1978. Apolipoprotein quantitation. In The Lipoprotein Molecule. H. Peeters, editor. Plenum Publishing Corp., New York.

16. Gustafson, A. 1965. New method for partial delipidization of serum lipoproteins. J. Lipid Res. 6: 512-516.

17. Albers, J. J., P. W. Wahl, V. G. Cabana, W. R. Hazzard, and J. J. Hoover. 1976. Quantitation of apolipoprotein A-I of human plasma high density lipoprotein. Metabolism. 25: 633-644.

18. Cheung, M. C., and J. J. Albers. 1977. The measurement of apolipoprotein A-I and A-II levels in men and women by immunoassay. J. Clin. Invest. 60: 43-50.

19. McConathy, W. J., and P. Alaupovic. 1973. Isolation and partial characterization of apolipoprotein $\mathrm{D}$ : a protein moiety of the human plasma lipoprotein system. FEBS (Fed. Eur. Biochem. Soc.) Lett. 37: 178-182.

20. Subbaiah, P. V., J. J. Albers, C-H. Chen, and J. D. Bagdade. 1980. Low density lipoprotein-activated lyso- lecithin acylation of human plasma lecithin-cholesterol acyltransferase. Identity of lysolecithin acyltransferase and lecithin-cholesterol acyltransferase. J. Biol. Chem. 255: 9275-9280.

21. Dieplinger, H. and G. M. Kostner. 1979. A fast and simple method for LCAT determination: a modified enzymatic procedure. Fifth International Symposium on Atherosclerosis, Nov. 6-9, Houston, Tex. Abstracts of Oral Presentations (No. 101).

22. Dixon, W. J. and F. J. Macey. 1969. In Introduction to Statistical Analysis. McGraw-Hill Book Co., New York. 202, 207, 349.

23. Warnick, G. R., C. Mayfield, J. J. Albers, and W. R. Hazzard. 1979. A gel isoelectric focusing method for specific diagnosis of familial hyperlipoproteinemia type III. Clin. Chem. 25: 279-284.

24. Glomset, J., and K. Norum. 1973. The metabolic role of lecithin-cholesterol acyltransferase: perspectives from pathology. Adv. Lipid Res. 11: 1-65.

25. Hamnstrøm, B., E. Gjone, and K. Norum. 1969. Familial plasma lecithin: cholesterol acyltransferase deficiency: report of a Swedish family. Br. Med. J. 2: 283-287.

26. Marcel, Y. L., and O. Vezina. 1973. A method for the determination of the initial rate of reaction of lecithin: cholesterol acyltransferase in human plasma. Biochim. Biophys. Acta. 306: 497-504.

27. Lacko, A. G., H. L. Rutenberg, and L. A. Soloff. 1977. The influence of age and sex on the esterification of human serum cholesterol. Biochem. Med. 17: 275-283.

28. Patsch, W., H-J. Lisch, S. Sailer, and H. Braunsteiner. 1978. Initial cholesterol esterification rate in hyperlipoproteinemia: effects of triglyceride-rich lipoproteins. Eur. J. Clin. Invest. 8: 209-213.

29. Wallentin, L., B. Angelin, K. Einarsson, and B. Leijd 1978. Lecithin:cholesterol acyl transfer rate in plasma and its relation to lipoprotein concentrations and to kinetics of bile acids and triglycerides in hyperlipoproteinemic subjects. Scand. J. Clin. Lab. Invest. 38(150): 103-110.

30. Nordby, G., and K. R. Norum. 1978. Aspects of the role of lecithin:cholesterol acyltransferase in metabolism of triglycerides. Scand. J. Clin. Lab. Invest. 38(150): 111114.

31. Glomset, J. A., and J. L. Wright. 1964. Some properties of a cholesterol esterifying enzyme in human plasma. Biochim. Biophys. Acta. 89: 266-276. 